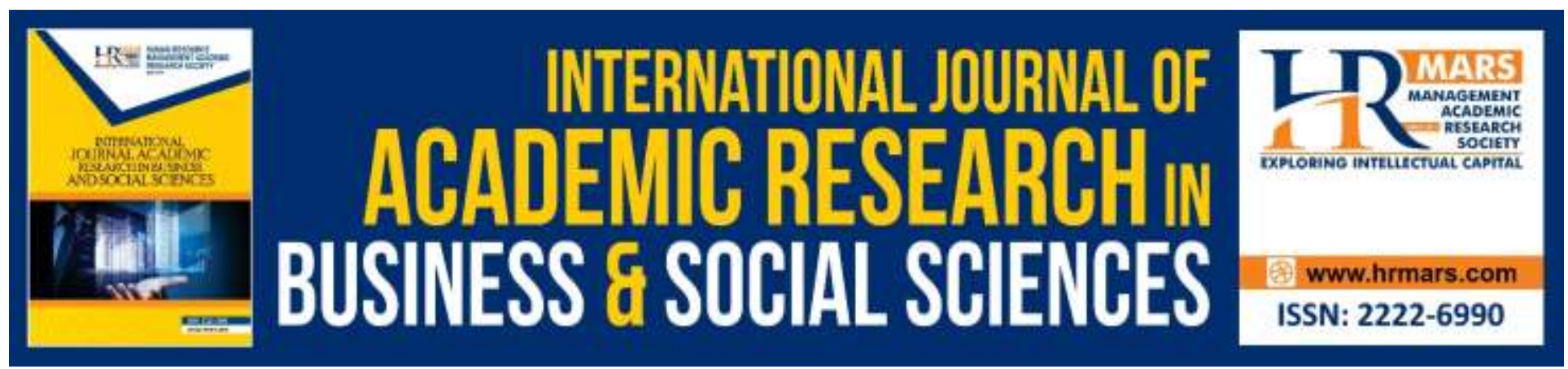

\title{
A Comprehensive Study on the Components of Al-Hawaij A/- Asliyyah (Basic Needs) in the Context of Social Justice for the Zakat Payer in Indonesia
}

Yuni Yulia Farikha, Muhammad Pisol Mat Isa

To Link this Article: http://dx.doi.org/10.6007/IJARBSS/v10-i5/7326

DOI:10.6007/IJARBSS/v10-i5/7326

Received: 15 March 2020, Revised: 12 April 2020, Accepted: 21 May 2020

Published Online: 30 May 2020

In-Text Citation: (Farikha \& Isa, 2020)

To Cite this Article: Farikha, Y. Y., \& Isa, M. P. M. (2020). A Comprehensive Study on the Components of Al-Hawaij Al-Asliyyah (Basic Needs) in the Context of Social Justice for the Zakat Payer in Indonesia. International Journal of Academic Research in Business and Social Sciences, 10(5), 951-986.

Copyright: (c) 2020 The Author(s)

Published by Human Resource Management Academic Research Society (www.hrmars.com)

This article is published under the Creative Commons Attribution (CC BY 4.0) license. Anyone may reproduce, distribute, translate and create derivative works of this article (for both commercial and non-commercial purposes), subject to full attribution to the original publication and authors. The full terms of this license may be seen at: http://creativecommons.org/licences/by/4.0/legalcode

Vol. 10, No. 5, 2020, Pg. 951 - 986

Full Terms \& Conditions of access and use can be found at http://hrmars.com/index.php/pages/detail/publication-ethics 


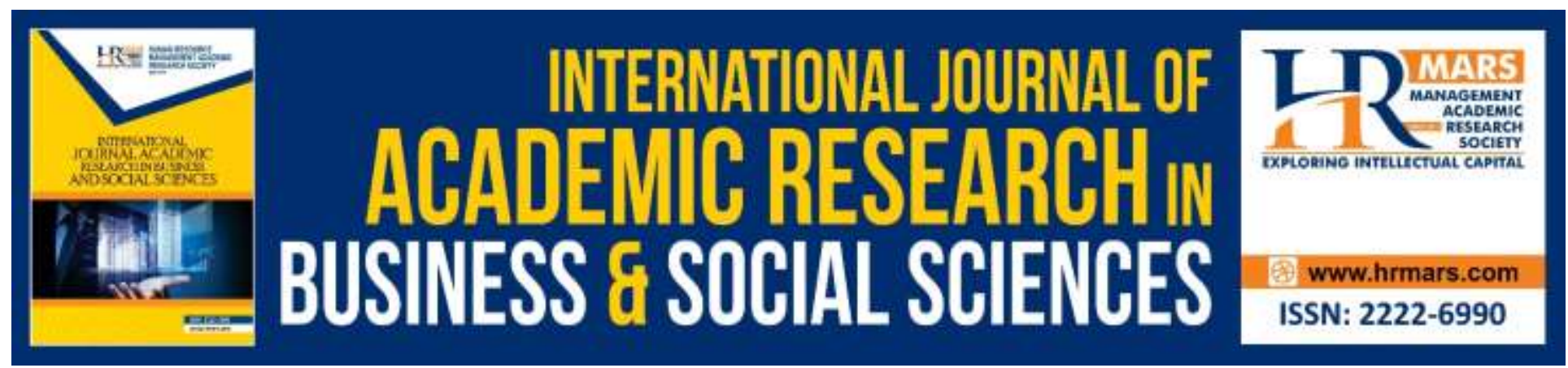

\title{
A Comprehensive Study on the Components of $A /-$ Hawaij Al-Asliyyah (Basic Needs) in the Context of Social Justice for the Zakat Payer in Indonesia
}

\author{
Yuni Yulia Farikha, Muhammad Pisol Mat Isa \\ Department Management \& Humanities, Universiti Teknologi Petronas, Malaysia
}

\begin{abstract}
One of zakat al mal al mustafad is zakat salary. Indonesia has high capability of collecting zakat. One of the requirements for performing zakat is the assets should exceed of al hawaij al asliyyah. Currently, not all the zakat institutions in Indonesia apply calculation of the standard exemption of zakat that measure al hawaij al asliyyah of individual. An exemption of zakat should have their own standard based on al hawaij al asliyah components in the society. This study is library research and will discuss on the components of al hawaij al asliyyah refer to the shariah views. There are ten of basic needs components mentioned in this paper. As recommendation, policy maker institution such as government and zakat institution should identify and investigate the amount of al hawaij al asliyah components periodically. Finally, through standard of al hawaij al asliyyah, it can achieve social justice of zakat payer in the collection of zakat salary in Indonesia.

Keywords: Zakat Salary, Al Hawaij Al Asliyah.
\end{abstract}

\section{Introduction}

Zakat as a pillar of Islam attracts the attention of Muslim economists nowadays. The existence of zakat organization grows in many Muslim countries and communities. It shows that the institution has positive contribution toward the problem of national economy. Zakat is a religious obligation that being as one of the pillars of Islam; an amount due on wealth and income of a Muslim. Literally, zakat means growth, increase and purify (Sabahaddin, 1985).

In the Qur'an, it is refreed as sadaqah. Thus, zakat is part of sadaqah that can be in the form of compulsory and voluntary. Zakat on wealth and zakat fitr are compulsory sadaqah. Whereas, waqf, hibah and all off the deeds are voluntary sadaqah. There are many benefits obtain when Muslims pay zakat. It is a mechanism of the distribution of wealth that can assist closing gap between the poor and the rich. It is mentioned in the holy Qur'an in surah al Tawbah verse 103. The meaning is "Take, (O Muhammad), from their wealth a charity by which you purify and cause 
them increase and invoke (Allah's blessing) upon them. Indeed, your invocations are reassurance for them. And Allah is Hearing and Knowing".

Essentially, zakat collection and distribution become the responsibility of the government as applied in the period of Abu Bakar ra. It is mentioned in the one hadith, when the Prophet (pbuh) sent Muadhz, he informed him that zakat is a transfer from rich to the poor people. As Tullock (1997) argues that the original motive of forming government was the desire for special types of redistribution. It proves that Islam as the way of life. Islam command Muslim to gain wealth but they cannot forget about other Muslims who need material assistance.

In the most of contemporary writing in the Islamic public finance, many scholars highlighted the socio-economic goals of zakat as stated by Mannan (1986), Haneef and Mahamud (2011), Norma and Abdullah (2011). Based on the previous study, there are many goals of zakat. First, it can be used to cover the moral, social and economic spheres of Islamic finance. Second, the aim is to promote economic growth and raise productivity through the circulation of wealth. Third, to meet the consumption demand of the poor and needy through multiplier effect that will increase the demand of investment and the economic growth of country. Fourth, to ensure equitable distribution of wealth and income, in the macro level zakat distribution will make individual member healthy and productive.

The data by IFAD (2011) shows that 1.4 billion people in developing countries live below the World Bank threshold of $\$ 1.25$ a day. Most of these poor are in Muslim countries and communities. Therefore, zakat collection and distribution can reduce the poverty. Furthermore, it will suppress the size of poor Muslims in the world. However, Haneef and Mahmud (2011) belief that zakat will only be success if the country provides an Islamic environment.

There are two form of zakats; zakat fitr (zakat for food) and zakat al mal (zakat of wealth) (al Qardawy, 2000). However, before any Muslim want to pay zakat al mal, he/she has to fulfil six conditions (1992). First, the ownership is fully owned by the zakat payer and the asset is either in the owner's possession without any restriction or it is held by another person but is under the owner's control. Second, the asset is growing or subject to grow. Third, the asset exceeds a minimum amount (nisab). Fourth, the asset exceeds basic personal (al hawaij al asliyah) and trade needs. Fifth, the asset is free of debt. Sixth, the asset has been held for one year (hawl).

Zakat has to be given to the poor and needy and other purposes as specified in the surah al Tawbah verses 60 that has meaning "Zakat expenditure is only for the poor and for the needy and for those employed to collect (zakat) and for bringing hearts together (for Islam) and for freeing captives (slaves) and for those in debt and for the cause of Allah and for the (stranded) traveler and obligation (imposed) by Allah. And Allah is Knowing and Wise".

Wahbah al Zuhaili (1994) mentions five categorizes of zakat as follow al 'ayn (gold and silver), al tijarah (trading), al harth (agriculture), al mashuyyah (animal product) and al rikaz (exploited assets). However, in Fiqh Zakat, Al Qardawi put another zakatable wealth which is zakatable assets, zakat on livestock, zakat on business inventory and zakat on earning of laborer's professional. All the zakatable wealth above is different in the calculation of nisab. In 
contemporary economic terminology, the other name of nisab is poverty line (Muhammad, 1992). The rate of nisab is 2.5 percent for all the wealth of ownership. But, for the agriculture zakat, the rate of nisab is 5 percent and 10 percent. For the plant with irrigation, the nisab is $5 \%$ whether the plant without irrigation is $10 \%$.

According to Firdaus et al (2011), Indonesia's zakat potential reach Rp. 217 trilion (USD 23 billion) and the zakat collection is 0.80 percent of the potential. Juwaini (2016) refer to the prediction Indonesia's zakat potential by Monzer Kahf that will achieve 237.9 trillion rupiah. It shows that there is huge number of the zakat potential need to be developed. The regulation about zakat states on Zakat Management Act No 23/2011. Zakat salary is mentioned in the articles 4 (3) (Yatimatul, 2012). It also states that the basic calculation on income imposed about $2.5 \%$ from the total income.

Zakat on salary is part of zakat al mal al mustafad (Zakaria, 1990). According to Dail (1984) zakat salary is not required to fulfil the hawl. Therefore, in the application, Muslim pay zakat direct after they earn monthly salary without wait until one year. Al Qardawi (1989), Haneef and Mahmud (2008) mentioned that its salary must be deducted from debt and expenses to fulfil basic needs (al hawaij al asliyah).

Al Qardawi (1989) mentions that a lot of basic needs today sometimes are not categorized in the basic need in the past. It can be changed and developed depend on the time and situation. He suggests focusing in this matter in every time and every place and the zakat organization must estimate al hawaij al asliyah periodically.

In the calculation of zakat, there are certain conditions that must be fulfilled by the zakat payer. One of the conditions is the wealth must be exceeded from al hawaij al asliyah (the basic needs). In Indonesia, not all the zakat institutions apply the standard of al hawaij al asliyah. Siswantoro (2011) depicts that three zakat institutions in Indonesia have different method of deduction of zakat salary. Different assumptions and theories in zakat calculation produced different calculation for zakat payer. He argues that this situation create divergence in the calculation result. For example, Dompet Dhuafa deducts monthly instalment from zakat salary, Rumah Zakat Indonesia (RZI) deducts the basic needs from zakat salary and BAZNAS does not deduct anything from zakat salary. RZI has a standard exemption in zakat calculation but it is not really reflecting to the amount of al hawaij al asliyah in Indonesia.

This situation raises question in justifying basic needs for zakat payer. It is important to discuss about al hawaij al asliyah on zakat salary. Thus, this paper will contribute to development of literatures related to al hawaij al asliyah on zakat salary and also recommend to further research that can define the component and also the exact amount of al hawaij al asliyah. It is needed to investigate the standard of living from different people with different size and income level of zakat payer in Indonesia. The result of the amount and percentage of al hawaij al asliyah components might be different with the current formula which applied by RZI. Here, policy maker institution such as government and zakat institutions should be set clear guideline in this matter 
as suggest by Mannan (1989), Al Qardawy (2000) and Haneef and Mahmud (2008). As an impact, it will be important information also to the zakat payers in Indonesia.

\section{Discussion}

\section{Zakat Salary}

Zakat is known as a section dedicated to the poor and the needy from the funds of riches (www.answers.com, 2015).Al Qardawy (2000) defines zakat al mal mustafad (earned income) is accrued assets or goods include regular income, periodical salaries and wages, grants, windfall profit, gift etc. He categorizes zakatable al mal al mustafad into four as follows:

1) Acquired assets resulted from owned capital such as profits on business

2) Accrued assets from high skill level of professionals

3) Accrued assets for labour compensation

4) Accrued asset based on the condition such marriage, decease, retirement etc

This paper will focus on zakat al mal al mustafad that accrued assets from high skill level of professionals and as known as zakat on income or zakat on salary. Zakat on salary is important, therefore several scholars strongly argue to impose zakat on salary on the ground of justice and consistency (Kahf, 1989). Jawhar (2008) defines income can be received from employment income and open income. Employment income as the reward of service such as periodically salary, arrears salary, allowances and other income related to employment. The opening of income can be created from the reward of the service rendered i.e legal services, counselling, consultation, health care, engineering, the arts and others.

Also, Hanan (2010) mentions that the term of zakat on salary as same as professional zakat. It is kind of zakat that be paid by professionals' fees. He classified professional zakat into two, namely personal private profession and institution profession. The profession that can be called as personal private profession are an architect and doctor. Meanwhile, public servant $s$ and ministers included as profession that depend on institution.

The obligation to pay zakat al mal al mustafad is based many verses in the qur'an. One of the verses is mentioned in surah al Baqarah verses 267.

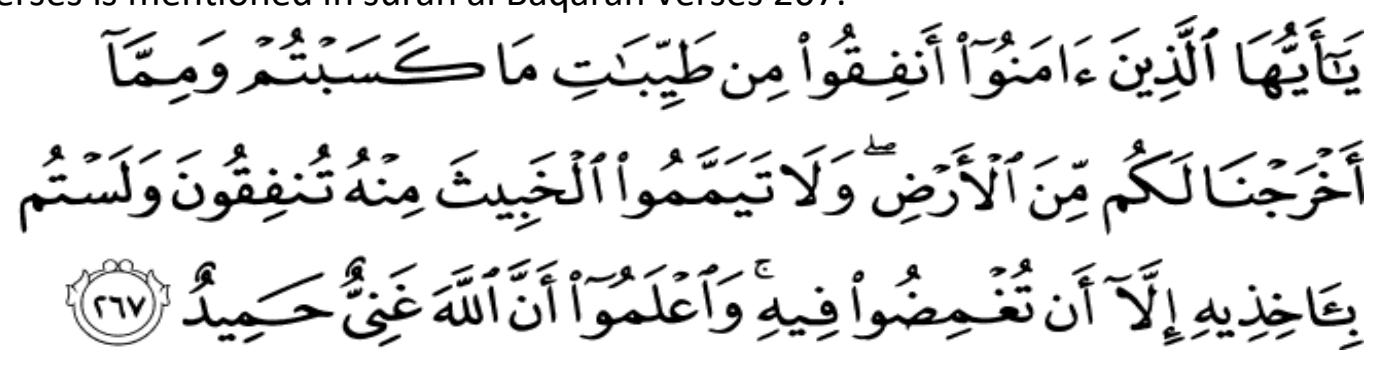

The meaning is "O you have believe, spend from the good things which you have earned and from that which we have produced for you from the earth. And do not aim toward the defective there from, spending (from that) while you would not take it (yourself) except with closed eyes. And know that Allah is free of need and Praiseworthy'. 
One hadits from Bukhari states "ala kulli muslim sadaqah", and according to Al Qurtubi, the hadits shows that zakat on salary is compulsory (Tarimin, 2012).

Many scholars have been discussed that zakat on salary is compulsory when it's acquired the nisab. Abu Ubayd in kitab Al Amwal, reported from Ibn 'Abbas about people who earns income, "He must pay its zakat the day he earns it" (Utami, 2006). Not only Ibn 'Abbas, but also another evidences from Ibn Mas'ud, Mu'awiyah, Al Sadiq, Al Baqir, Al Nasir, Daud, Imam Ahmad, Umar bin Abdul al 'aziz, al Hasan, al Zuhri and Al Awza'i view that al mal al mustafad are zakatable once they are earned without considering hawl or the passage of one year (al Qardhawi, 2000).

Another opinion that hawl is not required on zakat on salary, Dail (1984) argued that the hadits that supported no hawl on zakat salary is more authentic and stronger. He mentions one hadith Muslim "No zakat imposed on less than five camels, and no zakat imposed on silver that is less than five silver awaq and no zakat is imposed on grains if less than five awsuq". The hadits is not mentioned specific period ( $h a w l)$, therefore hawl is not requisite on zakat salary. However, there are some fuqoha also supported the opinion that hawl on zakat salary is compulsory (Ibn Qudamah, 1994). It is referring to the one hadith from Ibnu Majah that mentions: 'who own al mal al mustafad will not impose to pay zakat until the wealth achieved more than a year (hawl)' (Majid, 2003).

The application of zakat al mal al mustafad has been started since the period of prophet Muhammad saw even though it is not in a big number and the percentage is fluctuated (Tarimin, 2012). And also, not only in the form of money, al mal al mustafad can be paid in the form of stuff or consumptive goods. Khalifah Uthman bin Affan applied the zakat on salary direct from the rich people who their wealth already fulfils the nisab (Tarimin, 2012). Abi Shaibah reports that Umar Ibn Abd Al Aziz used to collect zakat on salaries and prizes and also Muawiyah Ibn Abi Sofyan was the first head of state that collected zakat salary.

\section{Previous Study on Zakat Salary}

There are numbers of researches on zakat al mal al mustafad. The researches talk about many issues especially in zakat on salary from different angles such as from shariah and fiqh perspective, juristic issues, comparison to the tax system, motivation to pay zakat and also factors that influenced Muslim to pay zakat income.

There are two studies in zakat salary that discussed more in shariah views of it. First, Dail (1984), he describes about zakat on salary and earned income: an analysis of its structure. The study focuses on the obligation of zakat on salary by referring to the stronger opinion from al Qur'an and hadits and also from many mazhabs. Second, Isa et al (2013) discussed about the zakat on salary in the issue of hawaij al asliyah in the application in zakat institution of Malaysia. This study discussed more in shariah view of zakat on salary and also criticizes on the practice of al hawaij al asliyah components. In Indonesia, the discussion about al hawaij al asliyah does not exist yet.

Many researchers are interested to study about the motivation to pay zakat salary and investigate the factors that influences Muslim to pay zakat on salary. Part of these studies done 
by Ali et. al. (2003), Ali et al (2004), Hairunizam and Sanep (2005), Kamil (2006), Walid et al (2006), Bidin (2008), Bidin and Idris (2009), Bakar (2010). Bakar and Rashid (2010) disclose that social, religious and economic factors influence the Muslim behaviour towards zakat on income in Malaysia. Also, the case study of Acheh (Ahmad et. al. ,2011) depict that factor of demography (gender and age), reference group, education and the perception of tax system was significantly influenced individual to pay zakat rather that zakat law.

Another research conducted in East Jakarta by Williasih et al (2011) found that regular zakah exercise does not automatically increase their quality life. Additionally, there was a relationship between spirituality and quality of life. On the other hand, Huda et al (2012) investigated the attitudes and control behaviour variables. They ascertained that these parameters have a positive and significant effect on the muzakki intention variable, whereas subjective norms do not. Abdullah et al (2014), they argue that zakat on salary is the unsettled juristic issues. On the other hand, Ali et al (2014) focused on taxpayer intention to pay zakat on salary. Lastly, Mohsin et al (2011) has conducted an investigation on zakat salary and EPF. They investigate shariah aspect on the validity of the payment of zakah on monthly salary in Malaysia and the validity of payment of zakat on EPF.

\section{The Importance of Al Hawaij Al Asliyah}

As mentioned earlier, one of the conditions subject to be zakat is the wealth must be excess from the al hawaij al asliyah (basic needs). This condition is according to Hanafiyah, Imam Bukhari and Ibn Kathir (al Qardawy, 2000). It supported by surah al Baqarah verses 219 which state "They will ask you what they should give a way? Say, what is surplus from your needs". Ibn Kathir defines "surplus" as in excess of you and your family's needs (Mahmud and Haneef, 2008). According to Islahi, it is very important that the payer of zakat is who rich people that can cover the needs of himself and his family. It is referred to one of hadits of Imam Ahmad with a statement of "sadaqa is to be taken from your rich and to be distributed to your poor people (Maududi, 1988).

Al hawaij al asliyah or al hawaij al asasiyyah can be named as daruriyah expenses (JAWHAR, 2008) or basic needs (Isa, 2013) or essential needs (Mahmud and haneef, 2008). Ibn Nujaim (1997) defines al hawaij al asliyah as something that can create difficulties if it does not exist. Imam Shatibi defines daruriyah as something that must and basic for the establishment of welfare in this world and hereafter. If we ignored, it would create chaos and disorder in our life.

The calculation of basic needs is important to achieve social justice to the zakat payer. Daud (2016) shows that the calculation of al hawaij al asliyyah and had kifayah can be strong foundation in the calculation of the real basic needs of individual. In fact, from the experience of Pusat Kutipan Zakat Pahang Malaysia, the collection of zakat will not drop because of the calculation. Moreover, the zakat payer will have strong confident and satisfy toward comprehensive calculation of basic needs when they pay zakat.

Tarimin (2016) use word Had Kifayah rather than use the word al hawaij al asliyyah to identify the basic needs of zakat payer and receiver, which is the needs of daruriyyah, hajiyat and tahsiniyat. By the understanding of the three needs of had kifayah, it will generate productive 
zakat payer and receiver, sustainable economic growth, health control, akidah and ubudiyah khalisah. He classified the existing of basic needs components into three parts. First part refers to Islamic jurisprudence book, namely shelter, house asistant, horse, weapon, social obligation, dependant, household equipment, health care, education, recreation, clothing, food, working equipment, loan, marriage, insurance and tax. Second part based on the current standard of zakat relief; shelter, clothing, food, education and transportation. Third part refer to tax relief by LHDN that consist of health care, education, defendants, saving, loan and security.

In fact, the components of basic needs are changing time to time based on the situation. Al Qardhawi (2008) emphasizes that al hawaij al asliyah here is not luxury goods; it is only covers essential goods and service to sustain himself and his defendants. He mentions that expenditure on holiday and buying luxury bungalow is not part of basic needs.

\section{The Components of Al Hawaij Al Asliyah}

As mentioned earlier, one of the conditions subject to be zakat is the wealth must be excess from the al hawaij al asliyah (basic needs). This condition is according to Hanafiyah, Imam Bukhari and Ibn Kathir (Al Qardawy, 2000). It supported by surah al Baqarah verses 29 which state "They will ask you what they should give a way? Say, what is surplus from your needs". Ibn Kathir defines "surplus" as in excess of you and your family's needs (Haneef and Mahmud, 2011). Moreover, alShaybani (Mustafa, 2011) states the basic needs cover for one's self, his family member and his parents, settling debt and saving. He defines the basic needs as food, clothing, shelter and means of transport as mentioned in one hadith; "Food to please your hunger with and clothing to cover yourself with. If you have a shelter to dwell in then it is good, and if you have an animal to ride so much better". Mustafa (2011) states the above hadith indicates that the basic needs vary according to time and place.

The basic needs of humankind states in surah Taha verses 118-119 (Hafidudhin, 2013). It states that "There is therein (enough provision) for you not to go hungry, nor go naked, nor go suffer from thirst nor from the sun's heat". Meaning that people needs food, clothing, water and shelter and Allah provide enough resource to fulfil human basic needs. And also mentions in surah alQuraish (106) verses 3 to 4 comprise the needs to perform worship; the needs on food, clothes and housing; and the needs to security and safety feeling.

Al Ghazali argues that the meaning of basic needs is flexible. It can be more inclusive; it will influence by the society condition at the given time but must be consistent with the Islamic shari'ah. According to him, they are three basic needs namely food, clothing and shelter. However, he mentions also about significant human needs that consist of furnishings, property, status and prestige and marital relations.

Al hawaij al asliyah or al hawaij al asasiyyah can be named as daruriyah expenses (JAWHAR, 2008) or basic needs (Isa MPM, 2013) or essential needs (Haneef and Mahmud, 2011). This study used word basic needs as synonym as al hawaij al asliyah. Ibn Nujaim (1997) defines al hawaij al asliyah as something that can create difficulties if it does not exist. Imam Shatibi describes 
INTERNATIONAL JOURNAL OF ACADEMIC RESEARCH IN BUSINESS AND SOCIAL SCIENCES

Vol. 10, No. 5, May, 2020, E-ISSN: 2222-6990 @ 2020 HRMARS

daruriyah as something that must and basic for the establishment of welfare in this world and hereafter. If we ignored, it would create chaos and disorder in our life.

Al Qardhawi (2000) emphasizes that al hawaij al asliyah here is not luxury goods; it is only covers essential goods and service to sustain himself and his defendants.

\section{Al Hawaij Al Asliyah in Malaysia}

In Malaysia, one of the zakat organizations which is Pusat Pungutan Zakat (PPZ) has a standard exemption in zakat calculation (www.zakat2u.com.my/pendapatan.php). It is a specific amount that represents the total basic needs of family in a year. It consists of six items as follow as individual expenditure is at RM 9000, spouse is at RM 3000, each child is at RM 1000, the actual number of money that given to their parent for one year, 11 percent of EPF and the actual number of their contributions or saving to pay zakat organization. In fact, the standard exemption of zakat in PPZ is taken from a few items of tax relief that presented by Inland Revenue Board of Malaysia (LHDN). The tax relief residential individual 2015 (www.hasil.gov.my) shows that there are 20 items mentioned in the individual relief types. On the other hand, every state in Malaysia has different policy in the management of zakat. Therefore it is different in the standard of zakat. Not all the state has guideline in the calculation of al hawaij al asliyah. Most of the zakat institution in Malaysia agree that zakat is from the nett asset or income. Daruriyah expenses is an ijtihadi (legal reasoning) issue (Perlis state shariah committee). It is guided by the opinion of ibn Abbas and Ibn Umar.

In Kelantan the established rate for daruriyah expenses must be the most moderate for one year. The rates cover personal expenses and that of their families. Thus the rate for personal expenses is at RM 5000, expenses for wife at RM 3000 and expenses for children is at RM 2000. These rate act as a general guide only because actual daruriyah expenses rate depends on the number of liabilities and other daruriyah expenses such as groceries and food, education, transportation costs and so on (Kelantan State Mufti Department, 1999). Selangor allows personal expenses of RM 8000, for a wife who does not work is at RM 5000 while for the parents is the actual expenses. This daruriyah expenses generally include personal expenses, spouse, children, parents and other responsibilities such as brothers, sisters, neighbours and travellers (guests). Daruriyah expenses also include obligatory contributions such as brothers, sisters, neighbours and travellers (guests). Daruriyah expenses also include obligatory contributions such as EPF contribution. The zakat rate is 2.5 percent on the net income (Jawhar, 2008).

One of province in Malaysia which is Pahang, under Pusat Zakat Kutipan Pahang (2016) applys nine components of basic needs in the zakat calculation. The components are food, shelter, clothing, health care, utility, transportation, education, communication and modern equipment. They calculate basic needs standard every two years. The latest survey in 2015, they investigate to 1500 respondents which is located in 14 of urban and rural area, they find standard amount of basic needs of individual, wife and children.

Sayin et. al. (2016) in 2015, has been done survey on the calculation of basic needs in 8 provinces in Malaysia, namely Johor, Kedah, Melaka, Perak, Pinang, Sabah, Selangor and Wilayah 
Persekutuan. It is qualitative and quantitative research. He investigates 6 components of basic needs which are shelter, food, education, clothing, health care and transportation. The calculation of basic needs apply for zakat payer and receiver of zakat also.

Sabani et. al. (2016) study on the calculation of basic needs of the student in University Teknology Mara (UITM) Malaysia. The finding is quite interesting since the student basic needs is slightly different to the society basic needs. They find basic needs of individual also academic needs. There are eight components of basic needs namely food and drink, shelter, transportation, clothing, health care, personal facilities, communication and expenses to go to their home town. On the other hand, academic needs included as tuition fee,club fee, reference book, printing, utility equipment, course work cost (in campus), course work cost (out campus) and uniform.

Isa (2013) tries to integrate the components of al hawaij al asliyah with the Consumer Price Index in Malaysia. However, not all the items in the CPI can be al hawaij al asliyah components. He suggests that the components of al hawaij al asliyah can be classified into ten components namely food and drink, clothing and shoes, housing and lighting, home furniture, health, transportation, communication, education, other loan (out of housing, furniture, transportation) and working equipment.

\section{The Component of Al Hawaij Al Asliyah in Indonesia}

One of the economic characteristics of zakat is income elasticity of zakat (Sabahaddin, 1985). Meaning that zakat is subject to increase and decrease in response to the variation of income. Income also become the major factor that determines consumption spending of the individual (Rashid et. al., 2011).

Different income among the population creates wider income disparity between the household. Stephen (2001) reveals that consumption and expenditure pattern changes along with the change in income level. Shamim and Ahmad (2007) investigate that there is significant gap between household expenditure and income disparity in rural and urban area. The study shows that an urban household will increase their consumption when their income is increased to improve their lifestyle.

To investigate al hawaij al asliyah on zakat al mal al mustafad it is close to the household expenditure survey. It happens because al hawaij al asliyah will discover the amount of basic needs components of zakat payer. Thus, household expenditure survey is also investigating the amount of basic needs of individual and family members. Household expenditure survey provides information about household income and consumption expenditure to measure the level and to observe the changes of living condition in the country (HIES, 2013). The survey describes budget limitation and choice according to their preferences on the other hand (Dudek and Koszela, 2013).

There are two different between conventional household expenditure survey and al hawaij al asliyah survey. First, the components of household expenditure are all the items that classified as basic needs, but in al hawaij al asliyah survey, the items of basic needs must be based on 
shariah requirement. For example, in the conventional household, alcoholic beverages and tobacco are categorized as basic needs components. However, since Islam prohibits alcoholic beverages for Muslim, thus alcoholic beverages will not be included as al hawaij al asliyah component survey. Second, not all the household will be investigated in the survey of al hawaij al aslliyah. It will only focus on household who earn income, or their salary is over the nisob. On the other hand, in conventional household survey, every household in all the level of income will be investigated as the subject of study.

In response to the current discussion and in the context of the study in Indonesia, the author refers to Average Monthly Expenditure per Capita in Rural Areas by Commodity Group and Monthly Expenditure per Capita Class, 2013-2014. The items mentioned are the latest and can be measured for al hawaij al-asliyyah components. Among the items found in table 1 can be categorized as the basic needs are as follows.

Table 1. Items and the percentage of average Monthly Expenditure 2014

\begin{tabular}{|c|c|c|c|}
\hline No & Items & Per capita Average & al hawaij al asliyyah \\
\hline 1 & Cereals & 54117 & $\mathrm{~V}$ \\
\hline 2 & Tubers & 2566 & $\mathrm{~V}$ \\
\hline 3 & Fish & 33385 & $\mathrm{~V}$ \\
\hline 4 & Meat & 19361 & $\mathrm{~V}$ \\
\hline 5 & Eggs and milk & 31508 & $\mathrm{~V}$ \\
\hline 6 & Vegetables & 30177 & $\mathrm{~V}$ \\
\hline 7 & Legumes & 11271 & $\mathrm{~V}$ \\
\hline 8 & Fruits & 23106 & V \\
\hline 9 & Oil and fats & 12412 & V \\
\hline 10 & Beverage stuffs & 12986 & $\mathrm{~V}$ \\
\hline 11 & Spices & 7538 & V \\
\hline 12 & Miscellaneous food items & 8484 & $\mathrm{x}$ \\
\hline 13 & $\begin{array}{lll}\begin{array}{l}\text { Prepared food } \\
\text { beverages }\end{array} & \text { and } \\
\end{array}$ & 142784 & $x$ \\
\hline 14 & Tobacco and betel & 50075 & $\mathrm{x}$ \\
\hline 15 & $\begin{array}{l}\text { Housing and household } \\
\text { facility }\end{array}$ & 227152 & V \\
\hline 16 & Goods and services & 131317 & $x$ \\
\hline 17 & Education cost & 44896 & $\mathrm{~V}$ \\
\hline 18 & Health cost & 32880 & $\mathrm{~V}$ \\
\hline 19 & $\begin{array}{l}\text { Clothing, footwear, and } \\
\text { headgear }\end{array}$ & 19221 & V \\
\hline 20 & Durable goods & 46915 & $x$ \\
\hline 21 & Taxes and insurances & 20903 & $\mathrm{~V}$ \\
\hline 22 & Parties and ceremonies & 15664 & $\mathrm{X}$ \\
\hline
\end{tabular}

Source: publication statistics Indonesia (October, 2016) 
INTERNATIONAL JOURNAL OF ACADEMIC RESEARCH IN BUSINESS AND SOCIAL SCIENCES

Vol. 10, No. 5, May, 2020, E-ISSN: 2222-6990 @ 2020 HRMARS

According to the previous studies, Shariah scholars proposed 10 components of al hawaij al asliyyah that included as al daruriyyat and al hajjiyat, as follow;

\section{Nutrition}

This component has important role in human life's. Nutrition consists of food, water and air. The availability of food should be enough and also the water and air should be clean. This component supported by Galtung (1980); Doyal \& Gough (1991); Ibn Abidin (1992); Sen (1993); Shubyr (1995); Qizilbash (1996); Al Shatibi (1997); Ibnu (1997); Narayan et al (2000); Biswas et al (2001); Human Right Commision of Malaysia (2003); Alkire et al (2011); Sulhi (2013); Isa (2013); Khan (2014).

\section{Clothing}

Basic function of cloth is to protect body from the weather. In the societies, dress is important feature of humankind. Moreover, in Islam clothing is essential to fulfill Allah obligation which is to cover aurah. Many literatures emphasize this component, such as Galtung (1980), Ibn Abidin (1992); Shubyr (1995); Qizilbash (1996); Al Shatibi (1997); Nawawi (2002), Human Right Commision of Malaysia (2003); Sulhi (2013), Isa et al (2013); Fahim (2014).

\section{Housing}

Housing is part of basic needs. It can be named as shelter. According to some researchers, among the requirements of a proper house are; it must have floor, toilet and electrics [55]. The previous research has been done by Galtung (1980); Doyal \& Gough (1991); Ibn Abidin (1992); Ibn Qudamah (1994); Shubyr (1995); Qizilbash (1996); Al Shatibi (1997); Al-Mawsilli (1998); Biswas et al (2001); Sa'di (2002); Human Right Commision of Malaysia (2003); Sulhi (2013); Isa (2013); Fahim (2014).

\section{Medical care}

This component has same meaning with health care or medical health. Currently, it is part of basic needs according to many view's such as Allardt (1993), Sen (1993); Qizilbash (1996); Narayan et al (2000); Nawawi (1998); Nusbaum (2003); Sulhi (2013); Isa (2013) and Fahim (2014).

\section{Working Equipment}

Most of every professional need equipment to facilitate his work. Therefore, some scholars agree that working equipment is included as basic needs components. The supporting idea comes from Ibn Abidin (1992); Allardt (1993); Uthman Shubyr (1995), Ibnu Nujaim (1997), Al Kasani (1998); Isa (2013). Mannan (1970) integrated the working equipment as the tool used for further production and also agriculture work.

\section{Education}

Some scholars included education as important thing in this life. Lack of education, it will create the problem in this life. Surah al Alaq verses 1 until 5 as the first surah that accepted by our prophet give evidence that Islam teach Muslim to read, to think and understand everything in this life in order to survive in this life. Also mentioned in hadits Al Bukhari that search of knowledge is compulsory for Muslim. Moreover, Hanif (2010) mentioned that the main problem 
that Muslim facing in this century is knowledge and education. Therefore, it is urgent for Muslim to have capability to access education whether in formal and non-formal institution in order to survive in this life. People should acquire basic education Doyal \& Gough (1991) and basic intellectual Qizilbash (1996). Education is symbolic of interaction and reflection (Galtung, 1980). It will show intelligence of people (Bieswar and Diener, 2001). Education is a part of basic needs also supported by Finnis (1980); Allardt (1993), Sen (1993); Nusbaum (2003); Alkire et al (2011); Sulhi (2013); Isa (2013); Fahim (2014).

\section{Furniture}

Mannan (1970) argues household utensils are part of basic needs. Every family need to have proper furniture at their house. This opinion supported by Shubyr (1995); Ibn Abidin (1992); Ibnu Nujaim (1997); Al Mawsili (1998); Sa'di (2002) and Isa (2013).

\section{Transportation}

People need transportation to support their activities. In the past, Manan (1970) emphasizes that riding animal has important role as transportation. Nowadays, the government should provide public transportation to facilitate for those do not have vehicles. Transportation is part of basic needs as mentioned by Ibnu Nujaim (1997); Shubyr (1995) Al Mawsili (1998), Sulhi (2013); Isa (2013); Fahim (2013).

\section{Communication}

It is part of basic needs as mentioned by Isa et al (2013).

\section{Recreation}

There are two opinions support that recreation is part of basic needs. It can create meaning full play (Finnis, 1980) and it can be opportunities to enjoy nature (Allard, 1993).

\section{Conclusion and Recommendation}

Given the above discussion, the investigation of al hawaij al asliyyah components and the calculation of the amount of al hawaij al asliyah components are important in the collection of zakat. It will create social justice to the zakat payer in Indonesia. Practically, as mentioned by Al Qardawy that policy maker such as government should have guideline about the standard al hawaij al asliyah periodically since the situation of economic will always change time to time and it will change al hawaij al asliyah components as well. As recommendation, it is urgent to conduct depth investigation on the components and calculation of al hawaij al asliyah based on the economic condition in Indonesia. First action is to finalize the components of al hawaij al asliyah, then proceed to investigate the amount of al hawaij al asliyah components through survey in every city whether urban and rural area, to the individual, wife also children. Finally, the result of this study will be useful for policy maker especially for zakat institution as a guideline of the standard exemption of zakat to achieve the social justice to zakat payer.

\section{Acknowledgement}

The authors would like to thank Universiti Teknologi PETRONAS (UTP) and the Department of Management and Humanities at UTP for the relentless support in realizing this study. 
INTERNATIONAL JOURNAL OF ACADEMIC RESEARCH IN BUSINESS AND SOCIAL SCIENCES

Vol. 10, No. 5, May, 2020, E-ISSN: 2222-6990 @ 2020 HRMARS

\section{Corresponding Author}

Yuni Yulia Farikha, PhD student in University Teknologi PETRONAS, Malaysia, yuni_g02826@utp.edu.my,

\section{References}

\section{Journal Article}

Abu, M. H., Ali, M. J., \& Khairul, M. Y. (2001). Management Accounting. Journal of Accounting, 42(1), 234-245.

Alkire, S., Foster, J., \& Santos, M. (2011). Where did Identification Go? Journal of Economic Inequality, 9(3). 501-505

Bakar, N. B. A., \& Rashid, H. M. A. (2010). Motivations of Paying Zakat Income: Evidence from Malaysia. International Journal of Economics \& Finance, 2 (3)

Bidin, Z., \& Mohd, I. K. (2009). Sikap, Norma Subjektif dan Kawalan Gelagat Ditanggap Terhadap Niat Gelagat Kepatuhan Zakat Pendapatan Gaji. International Journal of management Studies (UMS), 16 (1) 31-55

Biswas, D. R., \& Diener, E. (2001). Making the best of a bad situation: Satisfaction in the slums of Calcutta. Social Indicators Research, 55(3), 329-352

Bowen, G. (2009). Document Analysis as a Qualitative Research Method. Qualitative Research Journal

Dail, A. R. (1984). Zakat Gaji dan Pendapatan Bebas: Ditinjau dari Sudut Siyasah al Syar'iyyah. Paper presented at the Siyasah al Syar'iyyah, Universiti Kebangsaan Malaysia

Daud, M. H. (2016). Keperluan Penyelarasan Had Kifayah Zakat Pendapatan Malaysia. Konvesyen Zakat Kebangsaan 2016. Universiti Sains Islam Malaysia, 11-12 Oktober 2016

Dudek, H., \& Koszela, G. (2013). Comparison of Households' Expenditures Structures in Selected Countries of European Union. Warsaw University of Life Sciense, Scientiarum Polonorum ACTA, Economia 12 (3) 2013: 5-15

El Badawi, M. H., \& Al-Sultan, S. M. (1992). Net Working Capital versus Net Owner's equity Approaches to Computing Zakatable Amount: A Conceptual Comparison and Application. The American Journal of Islamic Social Sciences, 9 (1) pp 69-85

Firdaus, M., Syauqi, B.I., Irawan, T., Juanda, B. (2011). Economic Estimation and Determinations of Zakat Potential in Indonesia. IRTI Working Paper Series. WP\#1433-07

Hafidhuddin, D. (2013). Analisis Syariah Tentang Konsep Kemiskinan. Paper presented at National Focus Group Discussion on Islamic Poverty Line, Bogor

Haneef, S. S. S., \& Mahmud, W. M. (2011). Debatable Issues in Fiqh al Zakat; a Jurisprudential Appraisal. Journal Fiqh, Number 5

Huda, N., Rini, A. N., \& Putra, P. (2012). The Analysis of Attitudes, Subjective Norms, and Behavioral Control on Muzakki's Intention to Pay Zakah. International Journal of Business and Social Science, Vol. 3 No. 22 (Special Issue November 2012), 271

Idris K M. (2004). Kesan Persepsi Undang-Undang dan Penguatkuasaan Zakat Terhadap Gelagat Kepatuhan Zakat Pendapatan Gaji. Prosiding Muzakarah Pakar Zakat, Universiti Kebangsaan Malaysia, 201-212

Isa, M. P. M. (2013). Kepentingan Dirham Perak dalam Zakat. Paper presented at the Wacana Ilmu. Dewan al Qardhawi tingkat 7 wisma PPZ 
INTERNATIONAL JOURNAL OF ACADEMIC RESEARCH IN BUSINESS AND SOCIAL SCIENCES

Vol. 10, No. 5, May, 2020, E-ISSN: 2222-6990 @ 2020 HRMARS

Ismail, N., Mokhtar, Z. S., \& Abidin, Z. T. (2016). Isu Kontemporari Had Kifayah Zakat dan Pengurusan di Malaysia. Proceeding Konvesyen Zakat Kebangsaan, Universiti Sains Islam Malaysia, 11-12 Oktober 2016

Kahf, M. (1989). Zakat- Some Issues in the Contemporary Fiqh. Journal of Islamic Economics, Vol 2, Number 1, p1-22, 1989

Fahim, M., K. (2014). Consumer Behavior, Consumption Planning and Objectives of Shari'ah. Seminar/Workshop Developing a Framework for Maqasid al-shariah Based Index of SocioEconomic Development. Jeddah, Saudi Arabia, 30 April 2014

Muhammad D., A., Oladokun, N., \& Amin, B. F. M. (2013). "Zakat Distribution Among Asnaf in Wilayah and Selangor: Analytic Hierarchy Process (AHP)", Bayero International Journal of Islamic Finance, 1 (1)

Mustafa, O. M. (2011). Economic Consumption Model Revisited: Infaq Based on Al Shaybani's Level of Al Kasb. International Journal of Economic, Management \& Accounting, Suplementary Issues, 19, 115-132. International Islamic University Malaysia

Mohsin, M. I. A., Lahsasna, A., \& Ismail, E. (2011). Zakah from Salary and EPF: Issues and Challenges. International Journal of Business and Social Science. 2(1)

Nussbaum, M. C. (2003). Capabilities as Fundamental Entitlements: Sen and Social Justice. Feminist Economics. 9(2-3): 33-59

Sabahaddin, Z. (1985). Recent Interpretations of the Economic Aspect of Zakat. Seminar on Management Zakat in Modern Muslim Society, IRTI IDB, Jeddah.

Sabari, F. L., Abdullah, H. L., \& Hamdani, H. (2016). Kerangka Asas Penentuan Had makanan bagi Penentuan Had Kifayah: Kajian Preliminari. Konvesyen Zakat Kebangsaan. Universiti Sains Islam Malaysia, 11-12 Oktober 2016

Sapingi, R., Ahmad, N., \& Mohamad, M. (2011). A Study on Zakah of Employment Income: Factors That Influence Academics' Intention to Pay Zakah. Proceeding of $2^{\text {nd }}$ International Conference on Business and Economic Research (ICBER)

Sayin, B., Ran, M. A. M., Bhari, A., \& Saidon, R. (2016). Had Kifayat Zakat di Malaysia: Satu Analisis Perbandingan. Konvesyen Zakat Kebangsaan 2016. Universiti Sains Islam Malaysia 11-12 Oktober 2016

Shamim, F., \& Eatzaz, A. (2007). Understanding Household Consumption Patterns in Pakistan. Journal of retailing and Consumer Services

Siswantoro, D. (2011). ). The Need of Standardization of Individual Zakat Calculation in Indonesia". Tazkia Islamic Finance and Business Review. Volume7.1.109, 2011

Tarimin, M. (2016). Item Penolakan dan Kadar Had Kifayah Zakat Pendapatan dalam Islam. Konvesyen Zakat Kebangsaan; Universiti Sains Islam Malaysia 11-12 Oktober 2016

Zunaidah, B. A. H., Azhana, O., \& Nor, S. M. R. (2011). Relationship on Economic and Attitude Factors Towards Evasion on Zakat of Income: a Study among Public Servants in Melaka

\section{Book}

Albakri, M. B. Z. (2004). Siri Kajian Hukum Muamalat (siri pertama) Fatwa Zakat Kontemporer. Bank Muamalat.

Alkasani'. (1998). Bada'i al Sari' fi Tarhib al Shara'l. Tahqiq by M Adnan Al Darwish. Beirut: Dar al Ihya 'Al Turasi Al 'Arabi.

Almawsili, A. (1998). Al Iktiyar li Ta'lil Al Mukhtar. Damsyik: Dar Al Khayr. 
INTERNATIONAL JOURNAL OF ACADEMIC RESEARCH IN BUSINESS AND SOCIAL SCIENCES

Vol. 10, No. 5, May, 2020, E-ISSN: 2222-6990 @ 2020 HRMARS

Alshatibi. (1997). al Muwafaqat. Dar Ibn 'Affan.

Allardt, E. (1993). Having, Loving, Being: An alternative to the Swedish Model of Welfare Research. In M. C. Nussbaum \& A. Sen (Eds.). The Quality of Life (pp. 88-95). Oxford : Clarendon Press.

AlQaradawi, Y. (1989). Fiqh al-Zakat. English Translation by Monzer Kahf. King Abdul Aziz University: Jeddah Scientific Publishing Centre.

AlQaradawi, Y. (2000). Fiqh al-Zakat English Translation by Monzer Kahf 2nd volumes. King Abdul Aziz University: Jeddah Scientific Publishing Centre.

Aslam, H. (2010). Islamization of Knowledge: The Why, What and How. Malaysia: International Islamic University Malaysia.

Burns, N., \& Grove, S.K. (1999). Understanding Nursing research. Philadelphia: W.B. Saunders Company

Creswell, J. (2003). Research Design: Qualitative, Quantitative, and Mixed Method Approaches (2nd ed.). Thousand Oaks, California.: Sage Publications

Doyal, L., \& Gough, I. (1991). A Theory of Human Needs. New York: Guilford Press

Finnis, J. (1980). Natural Law and Natural Rights. Oxford: Oxford University Press

Galtung, J. (1980). The true worlds: A transnational perspective. New York: Free Press

Ghazanfar, M. S., \& Islahi, A. A. (

) Economic Thought of Ghazali. Islamic Economic Research Series, King Abdul Aziz University- 7

Hafidhuddin, D. (2002). Zakat Dalam Perekonomian Modern, Gema Insani: Jakarta

Human Rights Commission of Malaysia. (2003). Accessibility to Basic Needs: A Report of SUHAKAM's seminar on Economic, Social and Cultural Rights.

Ibn 'Abidin, M. (1992). Radd Al Muhtar 'ala al Durr al Mukhtar. Beirut: Dar al Fikr

Ibn, N., \& Zayn, A. B. I. (1997). al Bahr al Raiq fi al Kanz al Daqaiq. Saudi Arabia, Dar al Kutub Ilmiyah page 421

Ibn, Q., \& Abdallah, B. A. M. (1994), al Mughni tahqiq oleh Abdallah b Abd al Muhsin and Abd al Fattah Muhammad al Hilwi. Beirut, Dar al Fikr, j.6 c.3 page 176

Imam, N. M. A. (2002). Kitab al Zakah. Beirut, Dar al fikr

Israel, G. D. (1992). Determining Sample Size. Agriculture Education and Communication Department Series. Institute of Food and Agricultural Sciences. University of Florida

Jabatan Wakaf, Zakat dan Haji (JAWHAR). (2008). Manual Pengurusan Pengiraan Zakat, Putrajaya: Jabatan Wakaf, Zakat dan Haji

Juwaini, A. (2016). Kerangka Regulasi Sektor Filantropi di Indonesia: Peluang dan Tantangan. Routine ISEFID Discussion 23 September 2016.

Juwaini, A., \& Kalton, G. (1983). Introduction to Survey Sampling. United State of America : SAGE Publication.

Majid, A. Z. M. (2003). Pengurusan Zakat. Kuala Lumpur : Dewan Bahasa dan Pustaka

Mannan, M. A. (1970). Zakat in Islamic Economics Theory and Practice. Lahore : Sh. Muhammad Ashraf page 283-302

Mannan. (1986). M.A, Effects of Zakah Assessment and Collection on the Redistribution of Income in Contemporary Muslim Countries. Saudi Arabia : Islamic Development Bank

Maududi, ‘A. A. (1988). Maashiat-i-Islam, Islamic Publication, Lahore 
Merriam, S. (2009). Qualitative research: A guide to design and implementation: Revised and expanded from qualitative research and case study applications in education. San Franscisco: Jossey-Bass

Muhammad, U. S. (1995). Zakat al Usul al Thabutah al Ithtithmariyyah. Majalah AbhathwaA'mal al Nadwah al Khamisah li Qadaya al Zakat al Maasurah, Beirut, 18-20 April

Qizilbash, M. (1996). Ethical Development. World Development. 24(7): 1209-1221. Revised Zakat Disbursement Procedure Social Welfare and Rehabilitation (Approved by Central Zakat Council)

Sa'di, A. M. (2002). Fiqh Al Zakah was Mustajiddatuha al Mu'asirah. Jordan: Jamilah Mu'tah (hajat mustaqbaliyyah \& Hajat Hallah)

Saad, Norma, \& Abdullah, N. (2011). Is Zakat Capable of Alleviating Poverty? An Analysis on The Distribution of Zakat Fund in Malaysia, Al-Shajrah, ISTAC (forthcoming)

Sekaran, U. (2003). Research Methods for Business: A Skill-Building Approach (4th ed.). New York: John Wiley \& Sons

Sen, A. (1993). Capability and Well-Being. in A. Sen \& M. Nussbaum (Eds.), The Quality of Life. Clarendon: Oxford University Press

Sulhi. (1993). Zakat. Sudan: Dewan Al Zakat.

Tarimin, M. (1995). Sistem Zakat al Mal al Mustafad dalam Syariah Islam: Kajian Kes Pelaksanaannya di Wilayah Persekutuan Kuala Lumpur. Thesis (PhD) University Malaya

Tullock, G. (1997). Economics of Income Redistribution ( $2^{\text {nd }}$ edit). Kluwer Academic Publishers. London

Utami, Y. (2006). Yusuf Al Qadawy Contribution to the Contemporary Islamic Economic Thought. Master Thesis. International Islamic University Malaysia

Zuhaili, A. W. (1994). Terj. Md Khir Hj Yacoob, et all. Figh \& Perundangan Islam Jilid 3. Kuala Lumpur: Dewan Bahasa dan Pustaka

Zikmund, W. (2003). Business Research Methods (7th ed.). Mason, OH: Thomson/South-Western.

\section{Online Newspaper Articles}

Hanan, A. (2010) retrieved from

http://abuhannanassundawi.wordpress.com/2010/12/03/menyibak-kontroversi-zakat-profesi/

Kaedah Pengiraan zakat pendapatan. (2015). Retrieved from

https://www.zakat2u.com.my/pendapatan.php

Tax relief for residential individual. (2015). Retrieved from

http://www.hasil.gov.my/goindex.php?lgv=2\&chg=1

What is the importance of zakat in the light of quran? Retrieved 1 June 2015 from http://www.answers.com/Q/What_is_the_importance_of_zakat_in_the_light_of_quran

Technical and Research Reports (often with corporate authors):

Average Monthly Expenditure per Capita in Rural Areas by Commodity Group and Monthly Expenditure per Capita Class, 2013-2014 retrieved from

https://www.bps.go.id/linkTabelStatis/view/id/942

Household Income and Expenditure of Srilanka / HIES. (2013) Preliminary report, Department of

Census and Statistics Ministry of Finance and Planning Sri Lanka.

International Fund for Agriculture Development/IFAD. (2011). Rural Poverty Report 
INTERNATIONAL JOURNAL OF ACADEMIC RESEARCH IN BUSINESS AND SOCIAL SCIENCES

Vol. 10, No. 5, May, 2020, E-ISSN: 2222-6990 @ 2020 HRMARS

Narayan, D., Chambers, R., Shah, M. K., \& Petesch, P. (2000). Voices of the Poor: Crying out for Change. World Bank Publications. Washington: World Bank 